\title{
JUURNAL_RU
}

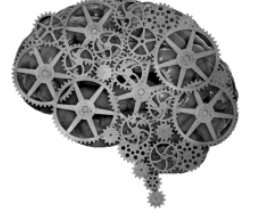

COMPANY GROUP "INTELLEKT"

\author{
Налимова М.А. \\ МБОУ «Сорская СОШ№3 с УИОП» \\ Сорск, Россия
}

doi: 10.18411/lj2016-5-4-05

\section{Сравнительный анализ систем гимнастики}

В период с конца XVIII в. происходят буржуазные революции во Франции, Испании, Португалии. Для успешного ведения войн с Наполеоном нужны были армии с хорошей военно-физической подготовкой, для этого потребовалось создание национальных систем гимнастики.

Филантрописты Фит (1763-1836) и Гуте Мутс (1759-1839) создали систему гимнастики, она дала две ветви. Одну ветвь Фридрих Людвиг превратил в немецкую гимнастику «турнкунст» или «турнен». Использовалась гимнастика в целях освобождения страны от оккупантов для подготовки молодежи. Основой были упражнения на снарядах и военные игры, развивающие физические силы и укрепляющие волю человека.

Другую ветвь Пер Генрих Линг (1776-1839) превратил в «шведскую гимнастику». Линг разработал гигиеническое направление, использовал упражнения, укрепляющие и развивающие тело человека, но не учитывал педагогическое значение гимнастики.

Его сын Р. Линг (1820-1886) разработал схему урока, состоящей из 16 частей, следовавших в строгом порядке одна за другой, создал систему классифицикации упражнений по анатомическому признаку, ввел специальные снаряды и ряд методических положений. При выполнении упражнений значение придавал положению частей тела: симметричности, прямолинейности и напряженности. 
В это же время Аморос (1770-1848) формировал французскую систему гимнастики, за основу он взял систему военно-физической подготовки А. В. Суворова. Использовал упражнения, которые помогают приобрести навыки, необходимые в жизни и военных условиях, использовал снаряды. Аморос рекомендовал использовать общие принципы: постепенности, последовательности, доступности, проводя урок, не придерживался определенной схемы. Была сделана первая попытка введения музыкального сопровождения на занятиях, упражнения исполнялись под военные песни, что возбуждало патриотические чувства.

В Чехии в середине XIX в. в связи с национально-освободительной борьбой стала создаваться сокольская система гимнастики. Ее основатель М. Тырш (1832-1884), он был знаком со всеми системами гимнастики, но считал их непригодными для организации массового гимнастического движения. Сокольская гимнастика напоминала немецкую гимнастику, но имела свои особенности. Основой были упражнения, вызывающие у исполнителей и зрителей эмоциональный подъем, чувство радости и эстетическое наслаждение, на гимнастических снарядах, упражнения с предметами и без них. Занятия проводились под музыкальное сопровождение, в единых костюмах, присуща четкость выполнения упражнений. Урок состоял из трех частей: в первой (подготовительной) части выполнялись порядковые упражнения, вольные или с предметами. Во второй (основной) части выполнялись упражнения на снарядах, прыжки. В третьей (заключительной) части применялись ходьба, умеренный бег, игры. Организация соревнований и массовых выступлений обеспечила успех во многих странах.

При Петре I были заложены основы физической подготовки войск, гимнастика была введена в военно-морских учебных заведениях. Стремление известных полководцев А. Румянцева, А. Суворова, адмирала Ф. Ушакова повысить уровень физической подготовки русской армии содействовало развитию гимнастики в России. 
А. В. Суворов создал систему военно-физической подготовки (1730-1800), в основу взял военно-полевую гимнастику, утреннюю гимнастику, закаливание. М. И. Драгомиров (1830-1915) поставил задачи физической подготовки для различных родов войск, разработал методику занятий гимнастикой в армии.

Для развития отечественной системы гимнастики внес огромный клад П. Ф. Лесгафт, изучив гимнастические системы на Западе, он пришел к выводу, что все указанные системы имели классовый характер и национальные традиции, их авторы не понимали педагогического значения гимнастики.

На развитие теории и практики физической культуры в нашей стране повлияло «Руководство по физическому образованию для детей школьного возраста» П. Ф. Лесгафта. Целью физического воспитания Лесгафт считал всестороннее гармоническое развитие человека. Задачи гимнастики: 1) способствовать правильному развитию нашего тела; 2) увеличение физической силы организма; 3) содействовать правильному определению отдельных органов нашего тела; 4) содействие правильному развитию формы тела. При выборе способов выполнения физических упражнений нужно опираться на педагогические задачи, а все упражнения должны отвечать анатомическому строению организма, его физиологическим функциям и педагогическим требованиям. Упражнения должны быть знакомы и все движения должны быть осознаны. Лесгафт показу предпочитал рассказ, прежде чем выполнять движение, требовал обязательного его продумывания учениками.

П. Ф. Лесгафт негативно относился к применению в школе упражнений на гимнастических снарядах, считая, что эти упражнения требуют больших напряжений, что приводит к чрезмерному утомлению. Считал, что соревнования совершенно не согласуются с задачами общеобразовательных школ и проводить их нельзя. Эти утверждения следует считать ошибочными. Практика современного физического воспитания доказывает полезность снарядовой гимнастики, прикладных видов упражнений и соревнований как неотъемлемой части учебного процесса. 
Проанализировав все рассмотренные системы, можно прийти к выводу, что их авторы недооценивали такие средства как слово педагога, музыка, условия проведения занятий, не всегда учитывались возможности не только отдельных групп упражнений, но и гимнастики в целом. Нужно отметить, что система П. Ф. Лесгафта была самой передовой, ее положения вошли в советскую систему физического воспитания.

\section{Литература:}

1. Князьков С., книга / Дворянство времен Петра Великого / Князьков С., Время Петра Великого. - М., 1991. - 397 - 408 с

2. Кун Л., книга / Всеобщая история физической культуры и спорта. М., 1982.

3. Столбов В.В., книга / Физическая культура и спорт в XVIII в. и первой половине XIX в. / В.В. Столбов, История и организация физической культуры и спорта. - М.,1982. - 68 - 70, 77-79 с. 